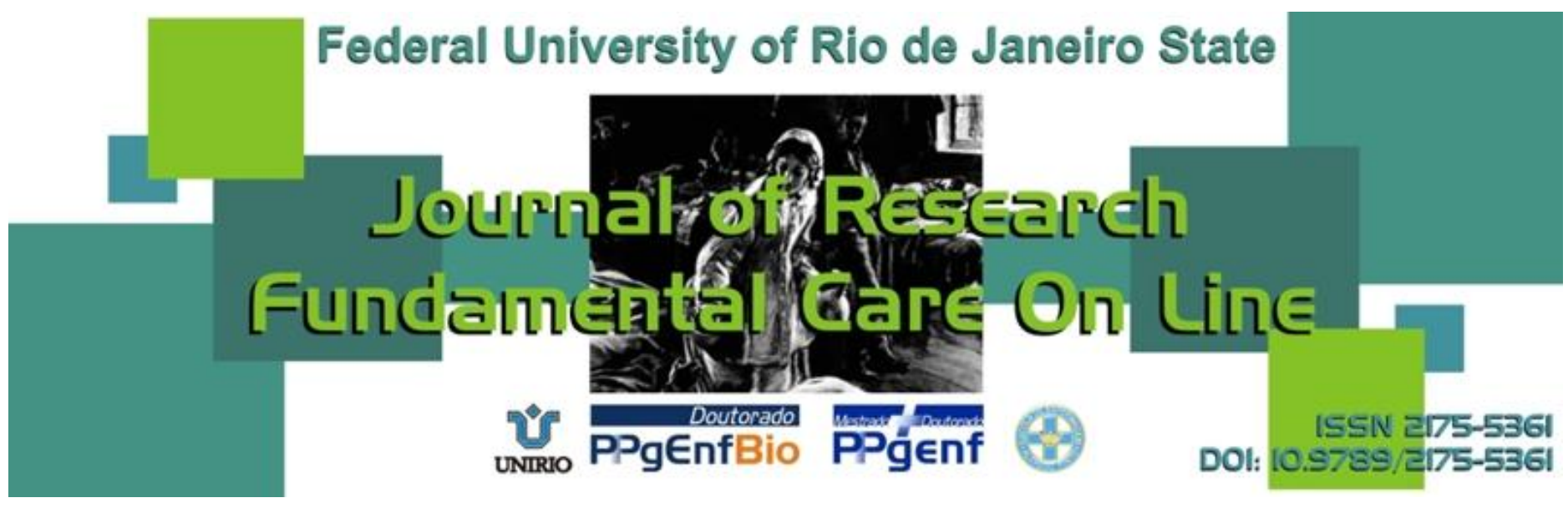

\title{
RESEARCH
}

\section{CONTEXTUAL ANALYSIS OF THE MEASUREMENT OF BLOOD PRESSURE IN CLINICAL PRACTICE}

ANÁLISE CONTEXTUAL DA MENSURAÇÃO DA PRESSÃO ARTERIAL NA PRÁTICA CLÍNICA

ANÁLISIS DEL CONTEXTO DE LA MEDICIÓN DE LA PRESIÓN ARTERIAL EN LA PRÁCTICA CLÍNICA

Manuela Pinto Tibúrcio ${ }^{1}$, Gilson de Vasconcelos Torres ${ }^{2}$, Bertha Cruz Enders ${ }^{3}$, Francis Solange Vieira Tourinho ${ }^{4}$, Gabriela de

Sousa Martins Melo ${ }^{5}$, Isabelle Katherinne Fernandes Costa ${ }^{6}$

\begin{abstract}
Objective: to analyze the contextual aspects of blood pressure measurement in clinical practice and understand the factors that determine this phenomenon. Method: Were selected 15 articles in the databases LILACS, MEDLINE and IBECS according with the inclusion criteria: published in Portuguese, Spanish or English, full text available between 2000-2011. For data analysis, used the contextual analysis. Results: In routine care, the blood pressure measurement is not being performed correctly by several professionals. Much of this failures stems from gaps in knowledge about the subject, both in technical aspects, as in anatomical and physiological. The client also interferes in the measure, especially with regard to their emotional state. Conclusion: Despite the auscultatory technique of blood pressure be simple, perceives an inadequacy in its implementation, possibly compromising the values and, consequently, the diagnosis, treatment and control of hypertension. Descriptors: Blood pressure determination, Hypertension, Nursing.
\end{abstract}

\section{RESUMO}

Objetivo: Analisar os aspectos contextuais da mensuração da pressão arterial na prática clínica e compreender os fatores que determinam este fenômeno. Método: Revisão de literatura realizada nas bases de dados LILACS, MEDLINE e IBECS. Foram selecionados 15 artigos segundo critérios de inclusão: publicados em português, inglês ou espanhol, texto completo disponível, entre 2000-2011. Para análise dos dados utilizou-se a análise contextual. Resultados: na rotina assistencial, a medida da pressão arterial não está sendo realizada de forma correta por diversos profissionais. Grande parte dessas falhas advém das lacunas no conhecimento sobre o assunto, tanto nos aspectos técnicos, como nos anátomofisiológicos. 0 cliente também interfere na mensuração, principalmente no que se refere ao seu estado emocional. Conclusão: Apesar da técnica auscultatória da PA ser simples, percebe-se uma inadequação em sua realização, podendo comprometer os valores obtidos e, consequentemente, o diagnóstico, tratamento e controle da hipertensão. Descritores: Determinação da pressão arterial, Hipertensão, Enfermagem.

\section{RESUMEN}

Objetivo: analizar los aspectos contextuales de la medición de la presión arterial en la práctica clínica y comprender los factores que determinan este fenómeno. Método: revisión bibliográfica hecha en las bases de datos LILACS, MEDLINE y IBECS. Se seleccionaron 15 artículos de acuerdo con criterios de inclusión: publicados en Portugués, Inglés o Español, disponibles texto completo, entre 2000- 2011. Para el análisis de datos se utilizó el análisis contextual. Resultados: En el cuidado de rutina, la medición de la presión arterial no se realiza correctamente por varios profesionales. Gran parte de este fracaso se debe a las lagunas del conocimiento sobre el tema, tanto en aspectos técnicos, como en los anatómicos fisiológicos. El cliente también interfiere en la medida, especialmente con respecto a su estado emocional. Conclusión: A pesar de la técnica de la ausculta de la presión arterial ser simple, se percibe la insuficiencia en su realización, que puede poner en peligro los valores y, en consecuencia, el diagnóstico, tratamiento y control de la hipertensión. Descriptores: Determinación de la presión sanguínea, Hipertensión, Enfermería.

${ }^{1}$ Nurse, Specialist in Occupational Health Nursing / FIP. Master's Program Graduate in Nursing / UFRN, a member of the research group Incubator Nursing Procedures / UFRN. ${ }^{2}$ Nurse. Post-doctorate in nursing, Professor Department of Nursing and the Graduate Program in Nursing / UFRN, PQ2 CNPq Researcher, coordinator of the research group Incubator Nursing Procedures / UFRN. ${ }^{3}$ Nurse, PhD Nursing from Texas Womans University (USA). Adjunct Professor at the Federal University of Rio Grande do Norte. ${ }^{4}$ Nurse, PhD in Child and Adolescent State University of Campinas. Fellow FAIMER Brazil-2011. Professor, Department of Nursing, Federal University of Rio Grande do Norte. ${ }^{5}$ Nurse. Master's Program Graduate in Nursing / UFRN, CNPq scholarship. Member of the research group Incubator Nursing Procedures / UFRN. ${ }^{6}$ Nurse. Doctoral Program Graduate in Nursing / UFRN, CAPES scholarship. Member of the research group Incubator Nursing Procedures / UFRN. 


\section{INTRODUCTION}

The importance of hypertension as a major cardiovascular risk factor, its high prevalence worldwide and the increased likelihood of outcomes circulatory fatal or non-fatal and disabling when it is associated with other risk factors, make it very important to be aware of its occurrence national and regional, early diagnosis and ongoing efforts to improve growing and therapy. ${ }^{1-2}$

A survey by the Ministry of Health made with 54000 adults reveals that the prevalence of the disease from 2006 to 2009, increased in all age groups, especially among the elderly. Currently, $63.2 \%$ of people aged 65 and over suffer from the problem against $57.8 \%$ in 2006. Among adults 45 to 54 years and 55 to 64 , the rate jumps to $34.4 \%$ and $50.4 \%$, respectively. This increase in the occurrence of the disease, according to age, is the result of dietary patterns and physical activity throughout life, in addition to genetic factors, stress and other factors. ${ }^{3}$

The accurate measurement of blood pressure (BP) is essential for the diagnosis of hypertension because its elevation is usually the first sign of the disease. Several methods are available to determine the pressure, and the indirect method with auscultatory the procedure most commonly used and easiest to apply, however, if not met certain principles for its implementation will be subject to several sources of error. Thus, for the accurate measurement of blood pressure and consequently the establishment of the correct diagnosis of hypertension, it is important to determine criteria in the development of this procedure, especially related to the environment, observant, patient and equipment used. ${ }^{4-5}$
Given the problems related to the BP measurement, especially the absence of specific educational programs and relevance of healthcare professionals in the assessment of this vital sign, the study aims to analyze the contextual aspects of blood pressure measurement in clinical practice and understand the factors that determine this phenomenon.

The results of this study will provide basis for constructing a protocol for measuring blood pressure in order to ensure the establishment of the correct diagnosis of hypertension, quality care to hospitalized patients and control and early detection of disease, as well as enable an expansion of scientific and therefore renewal of knowledge in this area.

\section{METHODOLOGY}

In the literature review is performed a collection of the most important specialized literature published about a specific topic, with further critical evaluation of findings. It has key role in academic work, because it is through lies a job within the large area of research which is part. ${ }^{6}$

Data collection was conducted through consultations on crawlers International Literature on Health Sciences (MEDLINE), Latin American Literature on Health Sciences (LILACS), Scientific Electronic Library Online (SciELO) and dissertations and theses in English and Portuguese.

We used the descriptors "determining blood pressure", "hypertension" and "nursing" with their respective terms in English (blood pressure determination, hypertension and nursing).

The inclusion criteria of definite articles for this literature review were studies published in English, Portuguese or Spanish, with full text available for the period 2000-2011, which reflect 
the contextual aspects of blood pressure measurement in clinical practice.

During collection, we selected a total of 67 articles distributed as follows: 3 in LILACS, MEDLINE and 1 in 63 in IBECS. After applying the inclusion criteria, reached up a corpus of 15 studies.

Among several proposed techniques for data analysis, we chose to use the contextual analysis of proposed by Hinds, Chaves and Cypress (1992). For the authors, the definition of context is based on the interaction purposeful, systematic and analytical professional with health situation or event, aiming to discover the meaning in its entirety and understand that every situation or event, to enable the prediction, explanation and understanding of the phenomenon. ${ }^{7}$

The framework is divided into four interactive layers: the immediate, focusing on the present and relevant aspects of the situation, as the space where the fact occurs and its limits; specific, whose main feature unique and individualized knowledge that encompasses the immediate past and the relevant aspects of this situation, the general, which is based on interpretations of individuals obtained through interactions past and present; the meta-context, socially constructed knowledge source that operates continuously and that results in a shared social vision. All layers are distinguished from each other and ranging from the fully individualized meaning to the universal meaning. ${ }^{7}$

\section{RESULTS AND DISCUSSION}

The results were categorized into subtopics, from the perspective of conceptual contexts presented by Hinds, Chaves and Cypress. ${ }^{7}$ Being named according to each context, they are: blood pressure measurement in clinical practice (immediate context); flaws that compromise the blood pressure measurement (specific context), when the emotional aspect starts to interfere with J. res.: fundam. care. online 2013. jul./set. 5(3):328-336 blood pressure measurement (general context), the blood pressure measurement: how should it happen? (meta-context).

A blood pressure measurement in clinical practice

The blood pressure measured by the classical technique proposed for over a century by RivaRocci, is one of the most widespread medical procedures and possibly performed. In recent decades, it has been questioned as to its accuracy. However, for more questioning of the method, it is still, for many years and should be one of the most important medical actions and fundamental in clinical practice, whether in emergency situations or in conditions of office. ${ }^{8}$

After more than a century, the indirect method with auscultatory technique is the most used resource for blood pressure measurement in clinical practice. The mercury manometers are considered the most reliable in any comparison made experimentally with other instruments. However, the day-to-day, aneroid devices are mostly used due to its lower price and size, despite showing lower accuracy. For this reason, it is important that certain precautions are observed, in order to increase confidence in the values found using these devices. ${ }^{4}$

The auscultatory BP is a simple, easy to perform and when executed correctly values, actually provides reliable assessment of blood pressure for diagnosis and treatment of hypertension. ${ }^{4}$

But what happens in between different routine care professionals is that the blood pressure measurement is not performed correctly, can compromise the values and, consequently, the diagnosis, treatment and control of hypertension. ${ }^{9}$

Thus, it is possible to diagnose as hypertensive patients with blood pressure normal behavior or fail to diagnose hypertensive true. In the first case, an antihypertensive treatment is instituted and unnecessary, on the other, the 
Tibúrcio MP, Torres GV, Enders BC et al

individual will be deprived of appropriate therapy. ${ }^{8}$

The main determinants of any failure of BP measurement in clinical practice, are related to basic care to the patient, the equipment and the observer, including their responsibility for the technical implementation of measurement, recording and interpretation of the obtained values of these results. ${ }^{8}$

The flaws that compromise the blood pressure measurement

Regarding the role of the observer in measuring blood pressure, several systematic failures can be identified. Among them we can mention the lack of mental concentration, hearing impairment and incorrect interpretation of Korotkoff sounds, related to technical errors, the preference registry values for terminal digits "zero" or "five". 4

These failures occur because a large proportion of professionals has ignorance and doubts about conceptual aspects, technical and anatomofisiological factors that influence blood pressure. In terms of technical errors related to medical researchers and nurses at the University of São Paulo the most outstanding applicants: incorrect choice cuff, incorrect position of the cuff, non-pet level of systolic pressure with an error in the presence of auscultatory gap, speed deflation too fast, putting on clothes cuff, stethoscope excessive compression deforming the artery and using the diaphragm instead of the bell; eyes to gauge non-aligned; misidentification Korotkoff sounds, and tendency to rounding of blood pressure values. ${ }^{10}$

In line with the study, a survey conducted in a public hospital in São Paulo State, to evaluate the technique of BP measurement by health professionals, found that, of the total of 16 predetermined steps involving the measurement process, nurses and nursing technicians performed less than $50.0 \%$ of them. The explanation of the J. res.: fundam. care. online 2013. jul./set. 5(3):328-336
Contextual analysis of the...

procedure further the step patient was performed (97.1\%), while selecting the proper width of the cuff was made by only $6.7 \%$ of the sample. ${ }^{5}$

Another potential source of error that deserves mention is the rounding of values of $\mathrm{BP}$ measurement in terminal digits in five and zero, which may cause misdiagnosis and mismanagement of the treatment of hypertension. The difference in approach resulting values may characterize false diagnosis of normotension or hypertension. . $^{50}$

A survey of professionals working in a public hospital in São Paulo State showed a preference for registering with digit zero values for systolic blood pressure and $77.1 \%$ for diastolic blood pressure in $74.3 \%$ of the measures. A minority, represented by $17.2 \%$ recorded values with final digits for systolic and $14.4 \%$ for diastolic blood pressure between 2 and 8, while 5.7\% indicated odd digits ( 1 to 9 ) for pressure systolic and $11.4 \%$ did so for diastolic blood pressure. ${ }^{5}$

The error seems to have the digital preferred since the beginning of professional training. Observational study with nursing students showed clear preference for zero and only $16 \%$ for values terminated by the other digit. However, continuing education programs can prevent or correct errors related to blood pressure measurement. ${ }^{11}$

As if not enough inconsistencies in the measurement of PA, another worrying factor is the lack of records in the records of clients. In a study conducted at the clinic of a general hospital and teaching in the city of São Paulo, it was found that $67.0 \%$ of the queries had no blood pressure value recorded in the medical record, i.e., more than half of the queries analyzed despite having been sampled records of patients seen at the Hypertension Division, necessarily where the pressure is measured and recorded. ${ }^{11}$

Whereas the record in the medical record reflects the actions of the health team, it might 
Tibúrcio MP, Torres GV, Enders BC et al

be supposed that the effective implementation of the assessment of blood pressure is directly related to the existence of annotation. Therefore, a significant number of people might not have within the cardiovascular evaluation parameter vital blood pressure measured. ${ }^{12}$

When the emotional aspect starts to interfere with the blood pressure measurement

Besides the lack of knowledge, regarding the technical anatomo-fisiologic and also, it is worth noting the neglect and indifference on the part of health professionals, to obey a methodology minimally acceptable. The determination of blood pressure, a parameter which a century ago had promised to open new horizons, trivialized to the point of taking aspects of an authentic ritual, performed blindly so sloppy and disinterested. ${ }^{13}$

Clearly, many steps are not being taken during the blood pressure measurement, which was observed in all professional categories. Considering the importance of this evidence to obtain reliable values of blood pressure, we can deduce the gravity of these findings, leading directly to the impairment of the blood pressure values. $^{10}$

In the case of the client, the main source of error in the measurement of blood pressure is related to your emotional state. According to the current concept, the effects attributed to the emotional state comprise two distinct phenomena: the first represents an "alarm reaction", the response of the patient against a doctor who is also her strange person or even the anxiety created by the expectation of some outcome painful, a blood drive, for example, the second phenomenon is the familiar "white coat hypertension" defined condition where a person has persistently with BP values above normal in the office and persistently normal values for measurement methods obtained in environments far from health professionals, while excluding the

J. res.: fundam. care. online 2013. jul./set. 5(3):328-336
Contextual analysis of the...

interference of the observer and his vices record. $^{13-14}$

The mechanisms proposed to explain both the effect as white coat hypertension are not well established, but include anxiety or alert responses and conditioning. However, patients with white coat hypertension usually do not appear anxious or tachycardia in the office, there is no reliable clinical indicator that helps the suspected diagnosis. The information for the patient, that the measures are within household values can help. ${ }^{15-16}$

In an exploratory study in 32 hypertensive patients treated at two public hospitals in Ribeirão Preto / SP shows the categories of responses about what hinders pressure control. Note that most of the responses referred to the emotional aspects as factors that hinder the control of blood pressure. Within this category, responses were found linked to nervousness and irritation (60.0\%), concern (31.0\%) and anxiety (9.0\%). The occurrence of these emotional states by patients was associated with problems at home (35.0\%), inconvenience (21.0\%) and financial $(12.0 \%) .^{17}$

These same subjects when asked what they could do to control blood pressure, $30.0 \%$ of the responses referred to the field of emotional states. Thus, patients seem to leave the responsibility to seek control of the pressure, since they attribute to others the responsibility for their emotional states seem to hold the belief that they can do nothing to change this condition. ${ }^{17}$

The measurement of blood pressure: how should it happen?

The Hypertension (HTN) is currently considered a public health problem because of its magnitude, risk, difficulty in its control and high cost medical-social and, especially, for their participation in serious complications. This data can be considered alarming, since the chronic elevation of blood pressure is important 
cardiovascular risk factor and, if not treated properly, can lead to the inability of a large number of individuals. ${ }^{18}$

It is known that the most effective way of reducing the impact of cardiovascular disease at the population level is the development of actions to promote health and primary prevention, involving the family as a whole, since these people act, interact and react by adopting decisions as a group, as well as promote a continuous learning process of teaching. In this sense, diagnosis and effective treatment of hypertension should be priority in combating the growing prevalence and incidence of cardiovascular disease in our country. ${ }^{19-20}$

By agreeing to these authors realize the importance of providing a nursing care not only for patients with hypertension, but the family as a whole.

The determination of the population hypertension is complex and requires accurate measurement of blood pressure, as its elevation is usually the first sign of disease. However, the importance of its measurement and control addition, since the relationship between BP and risk of cardiovascular disease events is continuous, consistent and independent of other risk factors. The higher the BP, the greater the possibility of myocardial infarction, heart failure, stroke and kidney disease, currently recognized other additional risk factors. ${ }^{4-5}$

The preparation of patients for blood pressure measurement in the sitting position involves: explaining the procedure to the patient, keeping the patient at rest for at least 5 minutes in a calm, avoid full bladder, the practice of physical exercises 60 to 90 minutes before and intake of alcohol, coffee or food and no smoking 30 minutes before; Keep legs uncrossed, feet flat on the floor, leaning back in his chair and relaxed; remove clothing arm in which to place the cuff; place the arm at heart level (at the midpoint of J. res.: fundam. care. online 2013. jul./set. 5(3):328-336 the sternum or 4th intercostal space), supported with the palm facing upward and the elbow slightly flexed; Request to not talk during the measurement. 1

Already the procedure itself for measurement of blood pressure includes the following steps to be followed, as in figure 1.

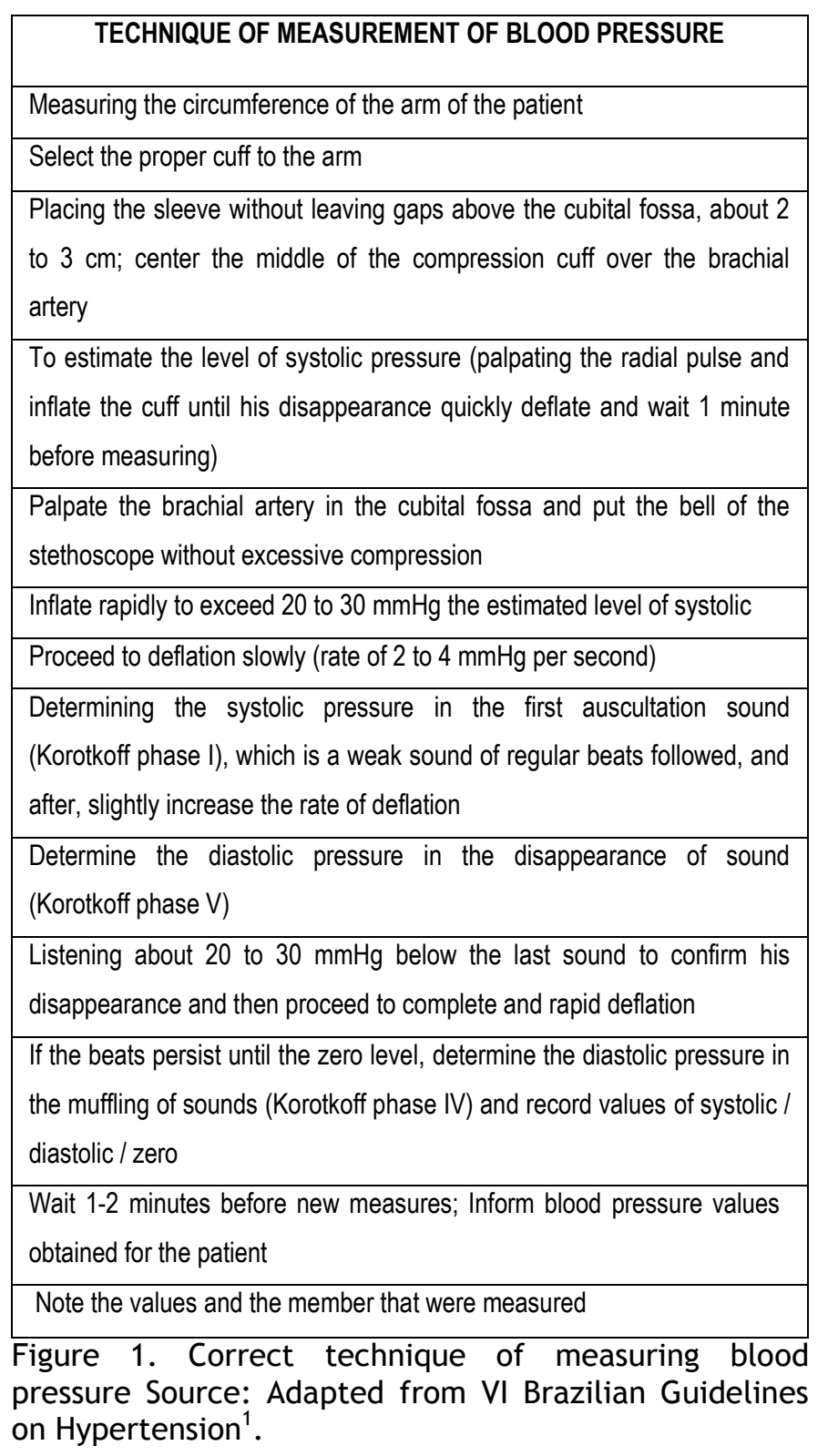

Several authors have argued in the literature the importance of careful measurement of blood pressure, because the values will ensure the establishment of the correct diagnosis of hypertension, defined precisely the treatment and control and ensure early detection of the disease. $^{10}$

\section{CONCLUSION}

Considering that thousands of people are diagnosed with hypertension worldwide, the 
Tibúrcio MP, Torres GV, Enders BC et al

indirect measurement of blood pressure is a very important technique that reveals a vital sign of the customer, enabling the vision of possible complications.

Data from this study show that, in routine care, the blood pressure is not being performed correctly by many professionals.

Much of this failure stems from gaps in knowledge on the subject, both in the technical aspects, as in anatomofisiological.

The client also interferes with the measurement of blood pressure, especially with regard to your emotional state, emphasizing the alarm reaction and coat hypertension involving anxiety or responses alert and conditioning during the procedure.

Given this context, there is an urgent need to develop campaigns that emphasize the role of nurses and all health professionals in the prevention and early detection of hypertension, but also as it relates to teaching people about the importance of the measure periodic blood pressure.

By portraying not so satisfactory results, the expectation of the authors on the literature review and discussion of the data is relevant and contribute material updated to programs of continuing education and teaching in undergraduate nursing.

\section{REFERENCES}

1. Sociedade Brasileira de Cardiologia / Sociedade Brasileira de Hipertensão / Sociedade Brasileira de Nefrologia. VI Diretrizes Brasileiras de Hipertensão. Arq Bras Cardiol [Internet] 2010 [cited 2011 Aug 1]; 95(1 supl.1): 1-51. Avaliable from:

http: / / publicacoes.cardiol.br/consenso/2010/Di retriz_hipertensao_associados.pdf

2. Silva JLM, Souza SL. Fatores de risco para hipertensão arterial sistêmica versus estilo de
Contextual analysis of the...

vida docente. Revista Eletrônica de Enfermagem [Internet]. 2004 [cited 2011 Aug 1]; 6(3): 330-335. Avaliable from: http://www.revistas.ufg.br/index.php/fen/arti cle/view/838/988

3. Brasil. Ministério da Saúde. Hipertensão arterial: Ações e Programas. Brasília; 2010. [cited 2011 Aug 2]. Avaliable from: http://portal.saude.gov.br/portal/aplicacoes/n oticias/default.cfm?pg=dspDetalheNoticia\&id_ar ea=124\&CO_NOTICIA=11290

4. Palota L, Cordella MP, Oliveira SM, Cesarino CB. A verificação da calibração dos manômetros e condições dos esfigmomanômetros aneróides: um programa de educação continuada para enfermeiros supervisores do Hospital de Base. Arq Ciênc Saúde [Internet]. 2004 [cited 2011 Aug 3];11(2):1-6. Avaliable from: http: //www.cienciasdasaude.famerp.br/racs_ol /Vol-11-2/ac06\%20-\%20id\%2011.pdf

5. Little P, Barnett J, Barnsley L, Marjoram J, Fitzgerald-Barron, Mant D. Avaliação de Técnicas da Medida da Pressão Arterial pelos Profissionais de Saúde. Arq Bras Cardio [Internet]. 2003 [cited 2011 Aug 12]; 80(1): 8388. Avaliable from: http: //www.scielo.br/pdf/abc/v80n1/14382.pd f

6. Cristante AF, Kfuri M. Como Escrever um Trabalho Científico. São Paulo: Sbot; 2010.

7. Hinds PS, Chaves D, Cypress SM. Context as a source of meaning and understanding. Qual Health Res.1992; 2(1):61-74.

8. Geilete TJM, Coelho EB, Nobre F. Medida casual da pressão arterial. Rev Bras Hipertens [Internet]. 2009 [cited 2011 Aug 26]; 16(2):11822. Avaliable from: http://departamentos.cardiol.br/dha/revista/1 6-2/13-medida.pdf. 
9. Veiga EV, Arcuri EAM, Cloutier L, Santos JLF. Medida da pressão arterial: circunferência braquial e disponibilidade de manguitos. Rev Latino-am Enfermagem [Internet]. 2009 [cited 2011 Sept 06]; 17(4). Avaliable from: http://www.scielo.br/pdf/rlae/v17n4/pt_04.pd f.

10. Pierin AMG, Cabral AH, Rabello CC, Pereira MGB, Mion Jr D. Registros dos valores da pressão arterial: preferência por dígitos terminais. Rev Hipertensão [Internet]. 2000 [cited 2011 Sept 06]; 3(4) 150-152. Avaliable from: http://www.sbh.org.br/revistas/2000/num4/pa rte5.pdf.

11. Alavarce DC, Pierin AMG, Mion Jr D. A pressão arterial está sendo medida? Rev Esc Enf USP [Internet]. 2000 [cited 2011 Sept 18]; 34(1): 84-90. Avaliable from: http: / /www.scielo.br/pdf/reeusp/v34n1/v34n1 a11.pdf.

12. Little P, Barnett J, Barnsley L, Marjoram J, Fitzgerald-Barron, Mant D. Comparison of agreement between different measures of blood pressure in primary care and daytime ambulatory blood pressure. BMJ [Internet]. 2002 [cited 2011 Sept 30]; 325(7358):254. Avaliable from: http://www.ncbi.nlm.nih.gov/pmc/articles/PM C117640/?tool=pubmed.

13. Kloetzel K. Uma lição esquecida: Como ler corretamente a Pressão Arterial. Rev. Diagn Tratamento [Internet]. 2003 [cited 2011 Sept 30]; 8(4):171-182. Avaliable from: http://apm1.locaweb.com.br/fechado/rdt_mat eria. aspx?idMateria $=277$.

14. Parati G, Valentini M. Do we need out-ofoffice blood pressure in every patient? Curr Opin Cardiol [Internet]. 2007 [cited 2011 Oct 01]; 22:321-8. Avaliable from: http: / / www.ncbi.nlm.nih.gov/pubmed/1755688 5

15. Sega R, Facchetti R, Bombelli M, Cesana G, Corrao G, Grassi G et al. Prognostic value of ambulatory and home blood pressures compared with office blood pressure in the general population: Follow-up results from the Pressioni Arteriose Monitorate e Loro Associazioni (PAMELA) study. Circulation [Internet]. 2005 [cited 2011 Oct 08]; 111:1777-83. Avaliable from:

http: //circ.ahajournals.org/content/111/14/17 77. full.pdf+html.

16. Kikuya M, Hansen TW, Thijs L, BjörklundBodegård $\mathrm{K}$, Kuznetsova $\mathrm{T}$, Ohkubo $\mathrm{T}$ et al. Diagnostic thresholds for ambulatory blood pressure monitoring based on 10-year cardiovascular risk. Circulation [Internet]. 2007 [cited 2011 Oct 08];115:2145-52. Avaliable from:

http: / / departamentos.cardiol.br/dha/revista/1 4-4/13-diagnostic.pdf.

17. Peres DS, Magna J M, Viana LA. Portador de hipertensão arterial: atitudes, crenças, percepções, pensamentos e práticas. Rev. Saúde Pública [Internet] 2003 [cited 2011 Oct 19]; 37(5): 635-642. Avaliable from: http: / /www.scielo.br/pdf/rsp/v37n5/17480.pdf

18. Gasperin D, Fensterseifer LM. As modificações do estilo de vida para hipertensos. Rev. Gaúcha Enferm [Internet] 2006 [cited 2011 Nov 10]; 27(3):372. Avaliable from: http://seer.ufrgs.br/RevistaGauchadeEnfermag em/article/view/4626/2638.

19. Gus I, Harzheim E, Zaslavsky C, Medina C, Gus M. Prevalência, reconhecimento e controle da hipertensão arterial sistêmica no estado do Rio Grande do Sul. Arq. Bras. Cardiol. [Internet] 2004 [cited 2011 Nov 10]; 83(5): 424-428. 
Avaliable

from:

http: / /www.scielo.br/pdf/abc/v83n5/22137.pd

f.

Medeiros EA, Santos VEP, Silva MDS, Santos SS, Matos KKC, Cruz NM, THE VISION OF CARE IN HYPERTENSIVE PATIENTS. Revista de Pesquisa Cuidado é Fundamental [Internet] 2012 [cited 2012 June 27]; 4(2): 2306-11. Avaliable from: http://www.seer.unirio.br/index.php/cuidadof undamental/article/view/1735.

\section{Received on: 13/08/2012}

Required for review: No

Approved on: 27/02/2013

Published on: 01/07/2013 